Bangladesh J. Bot. 40(1): 29-33, 2011 (June)

\title{
POLLEN MORPHOLOGY OF SOME TURKISH AJUGA L. (LAMIACEAE) AND ITS TAXONOMIC VALUE
}

\author{
Yavuz Bulent Kose, Ismuhan Potoglu Erkara ${ }^{*}$ and Sevim Alan \\ Department of Pharmaceutical Botany, Faculty of Pharmacy, \\ Anadolu University, 26470, Eskisehir, Turkey
}

Key words: Turkish Ajuga, Pollen morphology, Taxonomic value

\begin{abstract}
Pollen morphological structures of eight Turkish species of Ajuga, namely A. bombycina Boiss., A. chamaepitys (L.) Schreber ssp. chia var. chia (Schreber) Arcangeli, A. chamaepitys (L.) Schreber ssp. chia var. ciliata Briq., A. chamaepitys (L.) Schreber ssp. cuneatifolia (Stapf) P. H. Davis, A. genevensis L., A. laxmannii (L.) Benthum, A.orientalis L. and A. reptans L. have been studied under light and scanning electron microscopes for the first time. It is revealed that the pollen grains of Ajuga taxa are more or less suboblata-subprolata and tricolpatae. The exine sculpture is granulate in A. chamaepitys subsp. chia var. chia, A. chamaepitys subsp. cuneatifolia, A. genevensis, A. laxmannii, A. orientalis and A. reptans, but it is reticulate in A. bombycina and A. chamaepitys subsp. chia var. ciliata.
\end{abstract}

\section{Introduction}

The Lamiaceae is a large family and show world-wide natural distribution having approximately 250 genera, 7000 species in the world and 45 genera, 574 species in Turkey. Most of species belonging to this family are shrubby and herbaceus, trees extremely rare (Heywood 1978). This family has great importance due to its economic value (Koyuncu et al. 2010).

The genus Ajuga L. consists of about 90 species, mostly distributed in the north temperate zone of the old world. The genus also occurs in South Africa and Australia. In flora of Turkey Ajuga represented by 14 species and 27 subspesific taxa (Davis 1982,1988, Baytop 1999). Some Ajuga species have been widely used for their aromatic, diuretic, antipyretic, tonic, diaphoretic, astringent, bitter and homeopathic properties in the Turkish folk medicine (Baytop 1999) and in many official and unofficial medicine (Stuart 1979, Launert 1981, Werker et al. 1985, Bown 1995).

Very few anatomical studies is existed on Ajuga reptans L. and Ajuga chamaepitys (L.) Schreber ssp. chia (Schreber) Arcangeli var. chia in Turkey (Akçin et al. 2006, Potoglu Erkara and Koyuncu 2009). The pollen characters of some Turkish Ajuga species have yet studied to be in detail. Pollen structures can be used both to distinguish related taxa and integrate them into a common group.

The purpose of light microscopy (LM) and scanning electgronic microscopy (SEM) study on the pollen morphology of Turkish Ajugas, one of which is endemic species to solve problematic aspects of taxonomy and evolution.

\section{Materials and Methods}

Pollens were obtained from the authenticated voucher specimens deposited at the Faculty of Pharmacy of Anadolu University Herbarium (ESSE). For LM, pollen grains were processed from herbarium materials following Erdtman (1960). The pollen dimensions of all species were measured in such amounts that the resulting data followed Gaussian curves. These measurements

*Corresponding author. Department of Biology, Faculty of Science and Art, Eskisehir Osmangazi University, 26480, Meselik, Eskisehir, Turkey. E-mail: ismuhan@ogu.edu.tr, ismuhan@gmail.com. 
are shown in Table 2. For SEM, the unacetolyzed pollen grains were directly placed on stubs, sputter-coated with gold plate, and examined under a Jeol 5600 LV-SEM (Walker 1974a,b). The terminologies for pollen morphology proposed by Skvarla (1966), Erdtman (1969), Walker (1974a,b), Charpin et al. (1974) and Faegri and Iversen (1975) were employed.

\section{Specimens investigated}

\begin{tabular}{|c|c|c|}
\hline Taxa of Ajuga & Herbarium No. & Origin \\
\hline A. bombycina Boiss. (Endemic) & ESSE 14511 & $\begin{array}{l}\text { C4 Antalya, Alanya, kale çıkışı, yamaçlar, } 102 \mathrm{~m}, 36^{\circ} \\
32^{\prime} 21.1^{\prime \prime} \mathrm{N} 31^{\circ} 59^{\prime} 669^{\prime \prime} \text { E, 24/03/2010. }\end{array}$ \\
\hline $\begin{array}{l}\text { A. chamaepitys (L.) Schreber } \\
\text { subsp. chia var. chia } \\
\text { (Schreber) Arcangeli }\end{array}$ & ESSE 14508 & $\begin{array}{l}\text { C3 Antalya, Akseki, Güzelsu yolu, yol kenarı, } \\
\text { kayalik, } 1017 \mathrm{~m}, 36^{\circ} 54^{\prime} 32.2^{\prime \prime} \mathrm{N} 31^{\circ} 49^{\prime} 29.7^{\prime \prime} \mathrm{E} \text {, } \\
07 / 07 / 2008 \text {. }\end{array}$ \\
\hline $\begin{array}{l}\text { A. chamaepitys (L.) Schreber } \\
\text { subsp. chia var. ciliata Briq. }\end{array}$ & ESSE 14505 & $\begin{array}{l}\text { A1 (E) Kırklareli, Kofcaz-Ahmetli köyü yolu, } 5 . \mathrm{km} \text {, } \\
\text { Quercus orman1, } 683 \mathrm{~m} ., \mathrm{N} 41^{\circ} 58^{\prime} 08.2^{\prime \prime} \text { E } 27^{\circ} 09^{\prime} \\
38.6^{\prime \prime}, 17 / 06 / 2008 .\end{array}$ \\
\hline $\begin{array}{l}\text { Ajuga chamaepitys (L.) } \\
\text { Schreber subsp. cuneatifolia } \\
\text { (Stapf) PH Davis }\end{array}$ & ESSE 14507 & $\begin{array}{l}\text { C2 Burdur, Bucak, Çobanbeli, kayalık, } 847 \mathrm{~m}, 37^{\circ} \\
10^{\prime} 21.2 \mathrm{~N} 30^{\circ} 29^{\prime} 85.2^{\prime \prime} \text { E, 08/07/2008. }\end{array}$ \\
\hline A. genevensis L. & ESSE 14510 & $\begin{array}{l}\text { A1 (E) Kırklareli: Dereköy yolu, Dereköy'e } 10 \text { km } \\
\text { kala, Meşe koruluğu, } 449 \mathrm{~m}, 41^{\circ} 50^{\prime} 6.13^{\prime \prime} \mathrm{N} 27^{\circ} 18^{\prime} \\
3.18^{\prime \prime} \text { E, } 22 / 04 / 2009 \text {. }\end{array}$ \\
\hline A. laxmannii (L.) Bentham & ESSE 14503 & $\begin{array}{l}\text { A1 (E) Kırklareli, Kıyıköy-Vize arası, bozuk Quercus } \\
\text { orman1, } 298 \mathrm{~m}, 41^{\circ} 39^{\prime} 36.2^{\prime \prime} \mathrm{N} 27^{\circ} 53^{\prime} 41.9^{\prime \prime} \mathrm{E} \text {, } \\
\text { 16/06/2008. }\end{array}$ \\
\hline A. orientalis L. & ESSE 14504 & $\begin{array}{l}\text { A2 (A) Bursa, Uludağ, Oteller bölgesi, açk alan, } \\
1773 \text { m., } 40^{\circ} 06^{\prime} 23.2^{\prime \prime} \mathrm{N} 29^{\circ} 08^{\prime} 11.1^{\prime \prime} \mathrm{E}, 19 / 06 / 2008 .\end{array}$ \\
\hline A. reptans $\mathrm{L}$. & ESSE 14509 & $\begin{array}{l}\text { A2 (A) İstanbul: Sarıyer, İstanbul Ü. Orman Fak. } \\
\text { Araştırma Ormanı, Fındık suyu, Gürgen ormanı, } 41^{\circ} \\
09^{\prime} 77.7^{\prime \prime} \mathrm{N} 29^{\circ} 00^{\prime} 98.3^{\prime \prime} \mathrm{E}, 20 / 04 / 2009 \text {. }\end{array}$ \\
\hline
\end{tabular}

\section{Results and Discussion}

LM and SEM investigations show that the pollen grains of eight Ajuga taxa are more or less suboblata-subprolata and tricolpatae. The exine sculpture is granulate in A. chamaepitys subsp. chia var. chia, A. chamaepitys ssp. cuneatifolia, A. genevensis, A. laxmannii, A. orientalis and A. reptans, but reticulate in $A$. bombycina and $A$. chamaepitys ssp. chia var. ciliata. It has been reported that aperture features and exine structures are among the essential criteria for the determination of the phylogenetic relationships of the species of Ajuga (Kuprianova 1967, Cronquist 1968, Walker 1974a, b, Takhtajan 1980). The palynomorph of each of the species is described below:

A. bombycina (endemic): Pollen grains are suboblata-subprolata and tricolpatae, $\mathrm{P} / \mathrm{E}=1,27$ (A); ornamentation is tectatae-reticulatae; exine $1.04 \mu \mathrm{m}(\mathrm{A})$; tectum reticule (Fig. 1A-D, Table 1).

A. chamaepitys ssp. chia var. chia: Pollen grains are suboblata-subprolata and tricolpatae, $\mathrm{P} / \mathrm{E}$ $=1,32(\mathrm{~A})$; ornamentation is tectatae-granulatae; exine $1.42 \mu \mathrm{m}(\mathrm{A})$; tectum granule (Fig. 2A-D, Table 1). 
A. chamaepitys subsp. chia var. ciliata: Pollen grains are suboblata-subprolata and tricolpatae, $\mathrm{P} / \mathrm{E}=1.62(\mathrm{~A})$; ornamentation is tectatae-reticulatae; exine $1.02 \mu \mathrm{m}(\mathrm{A})$; tectum reticule (Fig. 3AD, Table 1).

A. chamaepitys ssp. cuneatifolia: Pollen grains are suboblata-subprolata and tricolpatae, $\mathrm{P} / \mathrm{E}=$ 1,24 (A); ornamentation is tectatae-granulatae; exine $1.1 \mu \mathrm{m}(\mathrm{A})$; tectum granule (Fig. 4A-D; Table 1).
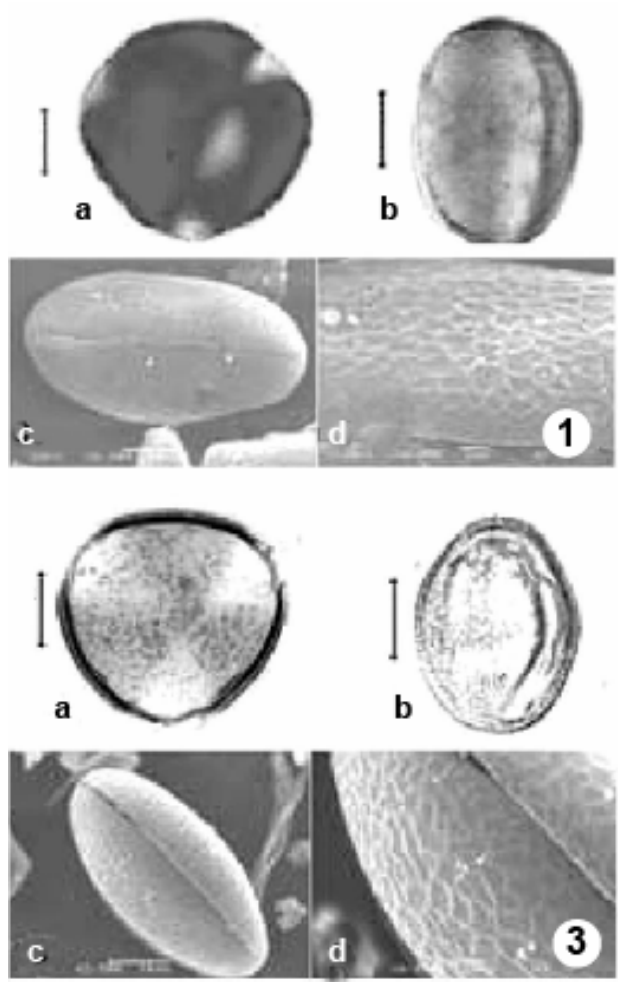

Figs 1-4. Pollen photomicrography. 1. Ajuga bombycina, 2. A. chamaepitys subsp. chia var. chia, 3. A. chamaepitys ssp. chia var. ciliata, 4. A. chamaepitys ssp. cuneatifolia, Polar view of an acetolysed pollen in light microscope (A). Equatorial view of a acetolysed pollen in light microscope (B). Scanning electron micrographs of pollen grains in equatorial view (C). Close up of pollen grains (D). Bars $=10 \mu \mathrm{m}$.

A. genevensis: Pollen grains are suboblata-subprolata and tricolpatae, $\mathrm{P} / \mathrm{E}=1.1(\mathrm{~A})$; ornamentation is tectatae-granulatae; exine $1 \mu \mathrm{m}(\mathrm{A})$; tectum granule (Fig. 5A-D, Table 1).

A. laxmannii: Pollen grains are suboblata-subprolata and tricolpatae, $\mathrm{P} / \mathrm{E}=1,11$ (A); ornamentation is tectatae-granulatae; exine $1.24 \mu \mathrm{m}(\mathrm{A})$; tectum granule (Fig. 6A-D; Table 1).

A. orientalis: Pollen grains are suboblata-subprolata and tricolpatae, $\mathrm{P} / \mathrm{E}=0.87(\mathrm{~A})$; ornamentation is tectatae-granulata; exine $1.64 \mu \mathrm{m}(\mathrm{A})$; tectum granule (Fig. 7A-D, Table 1).

A. reptans: Pollen grains are suboblata-subprolata and tricolpatae, $\mathrm{P} / \mathrm{E}=0.89$ (A); ornamentation is tectatae-granulatae; exine $1.46 \mu \mathrm{m}(\mathrm{A})$; tectum granule (Fig. 8A-D, Table 1).

The morphological features of exine layers in Ajuga have been reported as the features that best explain the nature of the phylogenetical relationship between taxa (Kuprianova 1967, Cronquist 1968, Walker 1974a, b, Takhtajan 1980). These results seem to suggest that the granulate and reticulate formation in the species of Ajuga could be a genotypic characteristic. 

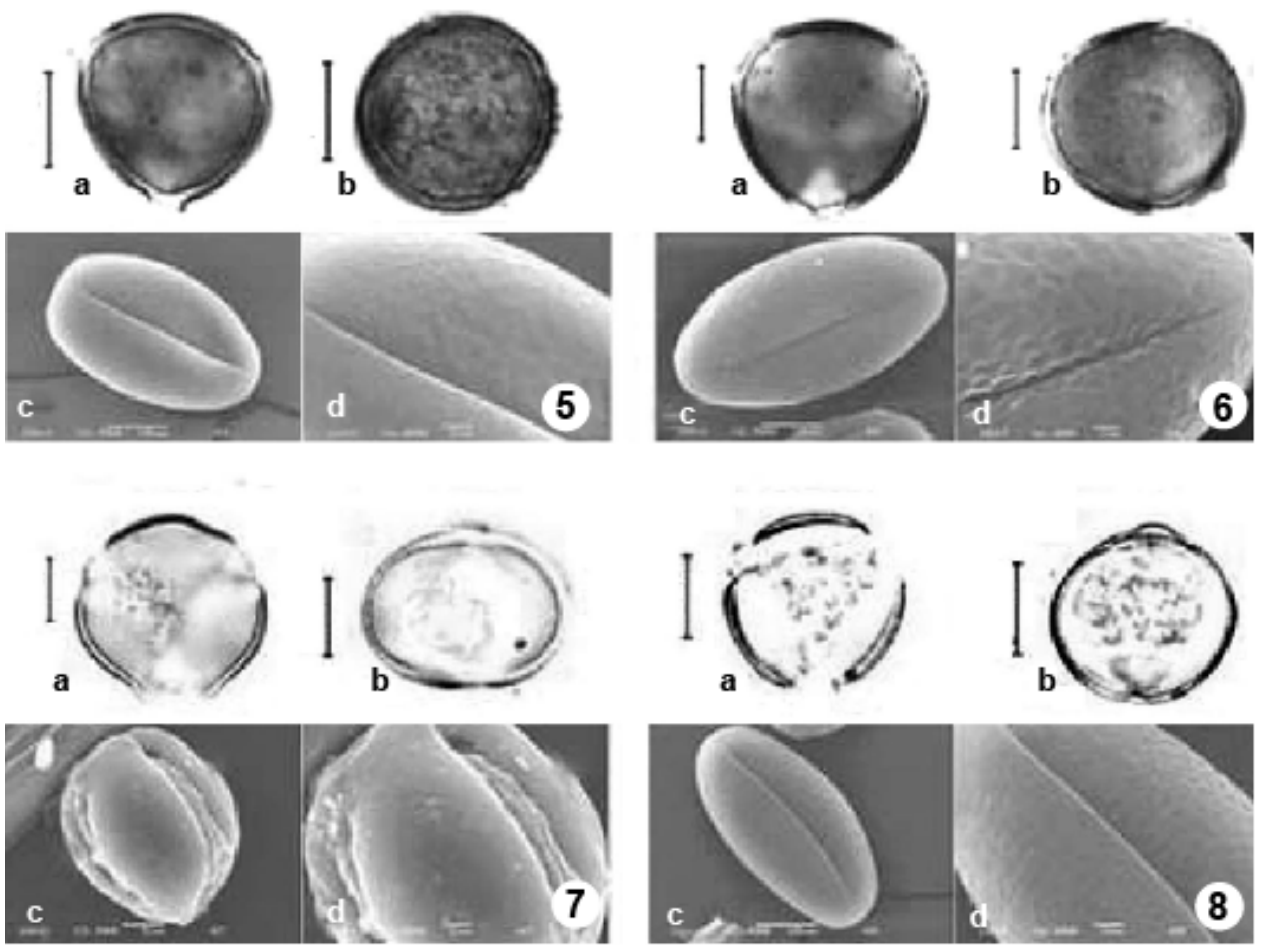

Figs 5-8. Pollen photomicrography. 5. Ajuga genevensis, 6. A. laxmannii, 7. A. orientalis and 8. A. reptans. Polar view of an acetolysed pollen in light microscope (A). Equatorial view of a acetolysed pollen in light microscope (B). Scanning electron micrographs of pollen grains in equatorial view (C). Close up of pollen grains (D). Bars $=10 \mu \mathrm{m}$.

Table 1. Morphometrical parameters and an identifying key of the pollen morphological features of investigated Ajuga taxa.

\begin{tabular}{lccccccccc}
\hline Taxa & $\mathrm{P}$ & $\mathrm{E}$ & $\mathrm{P} / \mathrm{E}$ & $\mathrm{L}$ & $\mathrm{clg}$ & $\mathrm{clt}$ & $\mathrm{t}$ & Exine & Tectum \\
\hline A. bombycina & 39.92 & 31.36 & 1.27 & 37.84 & 10.75 & 6.1 & $4.0 \pm$ & 1.04 & Reticule \\
& \pm 2.38 & \pm 3.24 & & \pm 2.58 & \pm 1.53 & \pm 1.79 & 0.60 & \pm 0.2 & \\
A. chamaepitys ssp. & 36.76 & 27.8 & 1.32 & 33.64 & 24.57 & 4.92 & $3.92 \pm$ & 1.42 & Granule \\
chia var. chia & \pm 2.87 & \pm 3.85 & & \pm 3.2 & \pm 4.1 & \pm 1.32 & 0.86 & \pm 0.47 & \\
A. chamaepitys ssp. & 29.88 & 18.44 & 1.62 & 27.92 & 25.37 & 4,96 & 4.64 & 1.02 & Reticule \\
chia var. ciliata & \pm 1.83 & \pm 1.35 & & \pm 1.93 & \pm 3.34 & \pm 0.89 & \pm 0.92 & \pm 0.17 & \\
A. chamaepitys ssp. & 37.52 & 30.32 & 1.24 & 35.28 & 8.86 & 5.9 & 3.93 & 1.1 & Granule \\
cuneatifolia & \pm 4.13 & \pm 3.87 & & \pm 4.21 & \pm 2.54 & \pm 3.01 & \pm 0.70 & \pm 0.2 & \\
A. genevensis & 23.56 & 21.6 & 1.1 & 21.56 & 10.3 & 4.7 & 3.83 & 1.0 & $"$ \\
& \pm 1.8 & \pm 1.93 & & \pm 1.8 & \pm 2.61 & \pm 1.34 & \pm 0.71 & \pm 0 & \\
A. laxmannii & 29.76 & 26.8 & 1.11 & 27.28 & 13.73 & 5.84 & 3.92 & 1.24 & $"$ \\
& \pm 1.45 & \pm 3.77 & & \pm 1.62 & \pm 4.1 & \pm 2.44 & \pm 1.32 & \pm 0.41 & \\
A. orientalis & 21.18 & 24.14 & 0.87 & 20.42 & 20.84 & 4.34 & 5.8 & 1.64 & $"$ \\
& \pm 2.10 & \pm 1.87 & & \pm 1.51 & \pm 3.54 & \pm 1.13 & \pm 1.96 & \pm 0.46 & \\
A. reptans & 19.02 & 21.32 & 0.89 & 23.15 & $21.8 \pm$ & 6.1 & 6.32 & 1.46 & $"$ \\
& \pm 2.15 & \pm 2.12 & & \pm 2.64 & 3.10 & \pm 1.94 & \pm 2.83 & \pm 0.42 & \\
\hline A. Acclons
\end{tabular}

A. Acetolysed pollen (LM); P. Polar axis; E. Equatorial axis; L. Equatorial countour diameter; clg. Length of the colpus; clt. Width of the colpus; t. Apocolpium. 
While LM revealed that Ajuga only had a granulate structure, detailed SEM showed that they were wrapped in both granules and reticules. We attributed such a difference in measurements to the fact that all the species analyzed had a genetic difference, which seems to comply with the claim that, in taxonomy, the sculpture types of pollens have valid morphological features (Cronquist 1968).

\section{Acknowledgement}

The supported by Anadolu University Research Projects Committee (Project No. AUAF 080307) is gratefully acknowledged.

\section{References}

Akçin OE, G Senel and Y Akçin 2006. The morphological and anatomical properties of Ajuga reptans L. and Ajuga chamaepitys (L.) Schreber subsp. chia (Schreber) Arcangeli var. chia (Lamiaceae) taxa. Pakistan J. Bio. Sci. 9 (2): 289-293.

Baytop T 1999. Therapy with medicinal plants in Turkey, past and present. ( $2^{\text {nd }}$ ed.) Nobel Tip Press., İstanbul, Turkey.

Bown D 1995. Encyclopaedia of herbs and their uses. Dorling Kindersley, London.

Charpin J, R Surinyach and AW Frankland 1974. Atlas of European Allergenic Pollens. Sandoz Editions, Paris, pp. 20-23.

Cronquist A 1968. The evolution and classification of the flowering plants. Thomas Nelson Ltd. Edinburgh, London.

Davis PH 1982. Flora of Turkey and The East Aegean Islands, Vol. 7, Edinburg Univ. Press, Edinburg.

Davis PH 1988. Flora of Turkey and The East Aegean Islands, Vol. 10, Edinburg Univ. Press, Edinburg.

Erdtman G 1960. The Acetolysis Method. A Revised Description. Suensk. Bot. Tidskr. 54: 561-564.

Erdtman G 1969. Handbook of palynology morphology, taxonomy, ecology. An Introduction to the study of Pollen Grains and Spores. Hafner Pub. New York.

Faegri K and J Iversen 1975. Textbook of pollen analysis. $\left(3^{\text {rd }}\right.$ Ed.) Munksgaard, Copenhagen.

Heywood VH 1978. Flowering plants of the world. Oxford Univ. Press, Oxford.

Koyuncu O, ÖK Yaylacı, D Öztürk, I Potoğlu Erkara, F Savaroğlu, Ö Akcoşkun and M Ardıç 2010. Risk categories and ethnobotanical features of the Lamiaceae taxa growing naturally in Osmaneli (Bilecik/Turkey) and environs. Biological Diversity and Conservation. 3 (3): 31-45.

Kuprianova A 1967. Apertures of pollen grains and their evolution in Angiosperms. Rev. Paleobot. Playnol. 3: $73-80$.

Launert E 1981. Edible and medicinal plants. Hamlyn

Potoglu Erkara, I and O Koyuncu 2009. The anatomical and palynological properties of Ajuga reptans L. (Lamiaceae) at risk. Anadolu Univ. Jo. Sci.Tech.10 (2): 593-601.

Skvarla JJ 1966. Techniques of pollen and spore electron microscopy. I. Staining, dehydration and embedding. Oklah. Geol. Notes 26: 179-186.

Stuart M (Ed) 1979. The Encyclopedia of herbs and herbalism. Orbis Publishing. London.

Takhtajan AL 1980. Outline of the classification of flowering plants (Magnoliophyta). Bot. Rev. 46: 225-359.

Walker JW 1974a. Evolution of exine structure in the pollen of primitive Angiosperms. Am. J. Bot. 61: 891902.

Walker JW 1974b. Aperture evolution in the pollen of primitive Angiosperms. Am. J. Bot. 61: 1112-1137.

Werker E, U Ravid and Y Putievsk 1985. Structure of glandular hairs and identification of the main components of their secreted material in some species of the Labiatae. Israel J. Bot. 34: 31-45. 